\title{
Nutritional implications of $D$-xylose in pigs
}

\author{
BY J. B. SCHUTTE, J. DE JONG AND R. POLZIEHN \\ TNO-Institute of Animal Nutrition and Physiology (ILOB), PO Box 15, 6700 AA Wageningen, \\ The Netherlands \\ AND M. W. A. VERSTEGEN \\ Department of Animal Nutrition, Agricultural University of Wageningen, Haagsteeg 4, 6708 PM \\ Wageningen, The Netherlands
}

(Received 28 June 1990 - Accepted 9 October 1990)

\begin{abstract}
Hemicellulose consists primarily of pentose sugars, joined together in a polysaccharide chain with Dxylose as the most abundant component. Ileal digestibility and urinary excretion of D-xylose and associated effects of this pentose sugar on ileal and faecal digestibility of dry matter (DM), organic matter (OM), gross energy (GE) and nitrogen were studied in pigs. Castrated pigs were prepared with a post-valvular T-caecum cannula to measure ileal digestibility. Faecal digestibility was measured in noncannulated pigs. D-Xylose was given at dietary inclusion levels of 100 and $200 \mathrm{~g} / \mathrm{kg}$, and the control sugar, D-glucose, at a rate of $200 \mathrm{~g} / \mathrm{kg}$ diet. Ileal digestibility of D-xylose as well as that of D-glucose was found to be close to $100 \%$. The presence of $\mathrm{D}$-xylose in the diet decreased ileal digesta $\mathrm{pH}$ and increased ileal flow of volatile fatty acids, suggesting the occurrence of microbial degradation of D-xylose in the pig small intestine. In pigs fed on the $100 \mathrm{~g} \mathrm{D}$-xylose $/ \mathrm{kg}$ diet, $44.5 \%$ of the D-xylose intake appeared in the urine. This percentage increased significantly to 52.6 when pigs were fed on the $200 \mathrm{~g}$ $\mathrm{D}$-xylose $/ \mathrm{kg}$ diet. Ileal and faecal digestibility of DM, OM, GE and $\mathrm{N}$, as well as $\mathrm{N}$ retention, decreased significantly in pigs fed on the $200 \mathrm{~g}$ D-xylose $/ \mathrm{kg}$ diet.
\end{abstract}

D-Xylose : Digestion: Excretion : Pig

Cellulose and hemicellulose form the bulk of the cell wall constituents of feed ingredients of vegetable origin. Both carbohydrate fractions are resistant to the digestive enzymes of pigs, and pass to the hind-gut where microbial degradation takes place. The microbial degradation of cellulose and hemicellulose in the hind-gut of pigs leads to the production of absorbable volatile fatty acids which provide energy to the animal (Imoto \& Namioka, 1978; Agricultural Research Council, 1981; Van Es, 1987). This fermentation process, however, is coupled with considerable losses in energy, assumed to vary between $33 \%$ (Agricultural Research Council, 1981) and 50\% (Just et al. 1983; Van Es, 1987).

Improving the utilization of cellulose and hemicellulose may be attained by an enzyme treatment which could hydrolyse these carbohydrate fractions to monosaccharides. There is little doubt that the monosaccharide units in cellulose, i.e. glucose, are an excellent source of energy for pigs. Hemicellulose primarily consists of pentose sugars, joined together in a polysaccharide chain with $\mathrm{D}$-xylose as the most abundant component.

The studies reported on the absorption of $D$-xylose relate to animal species other than pigs. These studies have shown that $\mathrm{D}$-xylose is readily absorbed from the intestinal tract by rats (Cori, 1925; Miller \& Lewis, 1932; Fowler \& Cooke, 1960; Arnal-Peyrot \& Adrian, 1974) and chicks (Wagh \& Waibel, 1967a). These studies also showed that part of the digested D-xylose is excreted in the urine. Findings on the utilization of D-xylose mainly relate to chicks. Longstaff et al. (1988) reported that chicks were able to grow well on diets 
Table 1. Composition of the basal diet $(\mathrm{g} / \mathrm{kg})$

\begin{tabular}{lc}
\hline Maize meal & 287 \\
Wheat starch & 287 \\
Soya-bean oil & 40 \\
Animal fat & 40 \\
Isolated soya protein $(880$ g protein $/ \mathrm{kg})$ & $223 \cdot 3$ \\
Cellulose* & 60 \\
Monocalcium phosphate & 24 \\
Limestone & 10 \\
Potassium bicarbonate & 15 \\
Iodized salt & 3 \\
Mineral mix $\dagger$ & 5 \\
Vitamin mix $\ddagger$ & 5 \\
DL-methionine & $0 \cdot 7$ \\
\hline
\end{tabular}

* Arbocel B 800 (Rettenmaier, FRG)

$\dagger$ Provided (mg/kg diet): magnesium 400, zinc 110, copper 25, manganese 45, iron 80, cobalt 0.5, selenium $0 \cdot 1$. $\ddagger$ Provided $(\mathrm{mg} / \mathrm{kg}$ diet): thiamin 2 , riboflavin 5 , nicotinamide 30 , pantothenic acid 12 , pyridoxine 3 , cyanocobalamin $0 \cdot 04$, biotin $0 \cdot 1$, folic acid 1 , menadione 3 , ascorbic acid 50 , retinol $3 \cdot 1$, cholecalciferol $0 \cdot 045$, vitamin $\mathrm{E} 40$, choline chloride 1000 .

Table 2. Chemical composition of the basal diet (analysed, $\mathrm{g} / \mathrm{kg}$ unless otherwise stated)

\begin{tabular}{llc}
\hline & & \\
\hline & Constituent & 909 \\
& Dry matter & 47 \\
Ash & 218 \\
Crude protein (nitrogen $\times 6.25)$ & 56 \\
Crude fibre & 86 \\
Crude fat & 17.9 \\
Gross energy $(\mathrm{MJ} / \mathrm{kg})$ & 9 \\
Calcium & 8 \\
\hline
\end{tabular}

containing D-xylose at a dietary concentration of $50 \mathrm{~g} / \mathrm{kg}$. Radioisotope studies by Wagh $\&$ Waibel $(1967 b)$ in chicks showed that D-xylose was metabolized to carbon dioxide, but less rapidly than D-glucose.

The present studies were designed to obtain information on ileal digestibility (absorbability) and urinary excretion of $\mathrm{D}$-xylose at dietary inclusion levels of 100 and $200 \mathrm{~g} / \mathrm{kg}$ in pigs. The effects of dietary D-xylose on the ileal and faecal digestibility of dry matter (DM), organic matter (OM), gross energy (GE) and nitrogen were also examined. $\mathrm{D}$-Glucose was included in the trials as a reference.

\section{MATERIALS AND METHODS \\ Animals and diets}

Two separate trials were conducted with growing castrated male pigs (Dutch Landrace $\times$ Dutch Yorkshire): one trial with cannulated pigs (Expt A) and one with non-cannulated pigs (Expt B). In both trials the pigs were individually housed in metabolism cages under a $12 \mathrm{~h}$ light $-12 \mathrm{~h}$ twilight cycle throughout. The nutritionally-complete basal diet used was based on maize, wheat starch and isolated soya-protein. The composition of the basal diet and its chemical characteristics are shown in Tables 1 and 2 respectively. The test sugars (D-glucose and D-xylose), supplied as anhydrous monosaccharides, were substituted by weight for wheat starch. 
In both trials the experimental diets were fed at a daily rate of $0.9 \mathrm{MJ}$ metabolizable energy (ME) $/ \mathrm{kg}$ metabolic body-weight $\left(\mathrm{BW}^{0 \cdot 75}\right)$, assuming that $\mathrm{D}-\mathrm{xylose}$ has the same $\mathrm{ME}$ content as D-glucose. The daily amount of feed was offered at two equal meals at 08.00 and 20.00 hours, and adjusted weekly according to body-weight. The feed was mixed with water ( 1 part feed +1 part water). In addition, water was freely available.

\section{Experimental protocol}

Expt $A$. The ileal digestibility of D-xylose, and the effect of this pentose sugar on ileal digestibility of DM, OM, GE and $\mathrm{N}$ were measured. Moreover, digesta $\mathrm{pH}$, concentrations of volatile fatty acids (VFA) in the digesta, and ileal flow of VFA were investigated.

Four pigs, 9 weeks old at the start of the trial, were involved. The pigs were surgically fitted with a post-valvular T-caecum cannula (PVTC) according to the procedure described by van Leeuwen et al. (1988). Post-operative care included keeping the pigs warm $\left(25^{\circ}\right)$ and witholding feed for $24 \mathrm{~h}$. During the 3-week post-operative period, the pigs were fed on the basal diet (Table 1). The experimental period lasted $24 \mathrm{~d}$ and consisted of three phases, during which time each pig was fed consecutively on a diet containing $200 \mathrm{~g}$ D-glucose $/ \mathrm{kg}$ (Gluc diet), $100 \mathrm{~g} \mathrm{D}$-xylose/kg (LL-Xyl diet) and $200 \mathrm{~g} \mathrm{D-xylose/kg} \mathrm{(HL-Xyl} \mathrm{diet),} \mathrm{with} \mathrm{a}$ $4 \mathrm{~d}$ adaptation and a $4 \mathrm{~d}$ collection period for each diet.

At the start of the experimental period, the pigs weighed on average 24.3 (SD 2.6) $\mathrm{kg}$ and at the end of this period 31.8 (SD 3.4$) \mathrm{kg}$.

Expt $B$. The objectives of this trial were to determine the urinary excretion of D-xylose, and to study the effect of D-xylose on faecal digestibility of DM, OM, GE and N, and N retention. This trial, involving four 9-week-old pigs, was run parallel with Expt A. The pigs were accustomed to cages and the basal diet (Table 1) for 3 weeks before starting the experimental period. The experimental design of Expt $\mathbf{B}$ was similar to that of Expt $\mathbf{A}$. During the $24 \mathrm{~d}$ experimental period the same three diets and batches of feed were used, and fed in the same order as described for Expt A.

At the start of the experimental period, the pigs weighed on average 25.0 (SD 0.7 ) $\mathrm{kg}$ and at the end of this period $34.4(\mathrm{SD} 0 \cdot 8) \mathrm{kg}$.

\section{Digesta collection}

During each $4 \mathrm{~d}$ collection period ileal digesta were collected quantitatively from individual animals over a $12 \mathrm{~h}$ period per day (08.00-20.00 hours). In this procedure it was assumed that ileal digestibility was completed within $12 \mathrm{~h}$. This assumption was based on previous studies (E. J. van Weerden, J. Huisman \& P. van Leeuwen; unpublished results) indicating that there were no significant differences in ileal digestibility when digesta were collected over a $12 \mathrm{~h}$ or over a $24 \mathrm{~h}$ period per day.

The digesta were collected continuously over dry ice, weighed daily and stored at $-20^{\circ}$. At the end of the experiment, the four $12 \mathrm{~h}$ collected portions were pooled for each pig separately, homogenized and sampled. The pH and VFA determinations were performed on the wet digesta, the other measurements on freeze-dried samples. Until analysis, all samples were kept at $-20^{\circ}$.

\section{Faeces and urine collection}

Faeces were collected directly into a bag fitted around the anus, and the urine was collected using a funnel fitted under the cage. Total collection of faeces and urine was carried out during the four $24 \mathrm{~h}$ collection periods from the individual animals at intervals of $12 \mathrm{~h}$. The faeces were stored at $-20^{\circ}$. All faeces produced during each collection period were pooled for each pig separately, homogenized and sampled. The samples were then freeze-dried before analysis. 
Urine was collected in containers provided with merthiolate (Thimerosal; BDH Chemicals Ltd, Poole, England) at intervals of approximately $4 \mathrm{~h}$. The portion from each interval was pooled daily from individual animals. A representative sample of $10 \%$ of the pooled urine was taken and frozen at $-20^{\circ}$. The $4 \mathrm{~d}$ sub-samples of urine were pooled for each animal separately, homogenized and sampled. Faeces and urine were kept at $-20^{\circ}$ between sampling and before analysis.

\section{Analytical methods}

Samples of feed and freeze-dried digesta and faeces were milled to pass through a $1.0 \mathrm{~mm}$ screen (Retsch mill ZM1; Retsch B. V., Ochten) before analysis. All analyses were carried out in duplicate. DM was determined by drying the samples to a constant weight at $101^{\circ}$. Inorganic matter and $\mathrm{N}$ were determined by standard methods (Association of Official Analytical Chemists, 1975), GE was determined using an IKA-C 4000 adiabatic bomb calorimeter.

Concentrations of VFA in wet digesta were determined by a modification of the gas liquid chromatographic method of Imoto \& Namioka (1978). A known portion (about $20 \mathrm{~g}$ ) of the digesta was centrifuged. Immediately afterwards the supernatant fraction $(5 \mathrm{ml})$ was acidified with $500 \mu \mathrm{l}$ phosphoric acid $(850 \mathrm{ml} / \mathrm{l}$, reagent grade), $3 \mathrm{ml}$ of an aqueous solution of isocapronic acid $(4.0193 \mathrm{~g} / 1)$ was added as an internal standard. Distilled water was then added to the mixture to obtain a final volume of $10 \mathrm{ml}$. A $1 \mu \mathrm{l}$ sample of the final solution was injected into the column of the gas-liquid chromatograph. The gas-liquid chromatograph was fitted with a flame-ionization detector (Packard 419, USA). A glass column (1850 $\mathrm{mm} \times 2 \mathrm{~mm}$ i.d.) packed with Chromosorb 101 of $80 / 100$ mesh was used. The carrier gas $\left(\mathrm{N}_{2}\right)$ was saturated with formic acid, and had a flow-rate of $25 \mathrm{ml} / \mathrm{min}$. The oven temperature was set at $190^{\circ}$, and the inlet and detector temperature at $225^{\circ}$. Standard solutions containing acetic acid, propionic acid, butyric acid, isobutyric acid, valeric acid and isovaleric acid were prepared for gas-liquid chromatography in the same way as described previously. Calibration curves for these acids were then made by obtaining the peak heights of the acids: that of isocapronic acid. Recovery values between 95 and $100 \%$ were found for the individual VFA and the internal standard. Total VFA was represented as the sum of all six acids.

Concentrations of glucose and xylose in digesta and urine were determined as silyl derivatives of monosaccharides by gas-liquid chromatography (Sweeley et al. 1963). A known amount of wet digesta $(1 \mathrm{~g})$ or urine $(1 \mathrm{ml})$ was diluted with distilled water $(1: 10$, $\mathrm{v} / \mathrm{v})$. The diluted sample was then deproteinized with potassium ferrocyanate and zinc acetate and desalted by passing through a mixture $(1: 1, w / w)$ of anion (Biorad AG $3 \times 4)$ and cation (Biorad AG $50 \mathrm{~W} \times 4$ )) exchanger. After centrifugation, $200 \mu \mathrm{l}$ of the supernatant fraction was freeze-dried. To the freeze-dried sample phenylglucopyranoside $(0.4 \mathrm{mg}$ in a $1 \mathrm{ml}$ pyridine solution) was added as an internal standard. The sample was then derivatized by the addition of $0.6 \mathrm{ml}$ hexamethyldisilazane and $0.3 \mathrm{ml}$ trimethylchlorosilane. The contents were mixed using a Vortex stirrer, and after an incubation period of $30 \mathrm{~min}$ at room temperature, the reagents were removed by evaporation with $\mathrm{N}_{2}$ at $40^{\circ}$. The residue was then redissolved in $0.5 \mathrm{ml}$ ethyl acetate. From this sample, $2 \mu 1$ was analysed using a Hewlett Packard HP 5890 gas-liquid chromatograph, equipped with a flame-ionization detector and a Hewlett Packard 3396A integrator.

The carbohydrate derivatives were separated with a chrompack capillar WCOT fused silica column, coated with $\mathrm{CP}$ sil $5 \mathrm{CB}$, of $50 \mathrm{~m}$ length. $\mathrm{H}_{2}$ was used as the carrier gas. The oven temperature was held for $3 \mathrm{~min}$ at $190^{\circ}$, then raised at the rate of $5^{\circ} / \mathrm{min}$ to a final temperature of $265^{\circ}$, which was held for $5 \mathrm{~min}$. The temperatures of the injector and detector were 240 and $300^{\circ}$ respectively. 
Table 3. Expt $A^{*}$. Intake $(\mathrm{g} / 12 \mathrm{~h})$ of dry matter $(D M)$ and water, output $(\mathrm{g} / 12 \mathrm{~h})$ of ileal digesta, and DM content $(\mathrm{g} / \mathrm{kg})$ of ileal digesta, measured in cannulated pigs fed on $D$-glucose and $D$-xylose $(100(L L-X y l)$ or $200(H L-X y l) \mathrm{g} / \mathrm{kg})$ diets

(Mean values of four pigs per treatment)

\begin{tabular}{lrrrr}
\hline \hline Diet ... & & \multicolumn{3}{c}{ SEM } \\
Intake of DM & Gluc & LL-Xyl & HL-Xyl & (df 6) \\
\hline Intake of water & $316^{\mathrm{a}}$ & $333^{\mathrm{b}}$ & $349^{\mathrm{c}}$ & $0 \cdot 3$ \\
Output of wet ileal digesta & $817^{\mathrm{a}}$ & $1029^{\mathrm{b}}$ & $1156^{\mathrm{b}}$ & $53 \cdot 4$ \\
DM content ileal digesta & $255^{\mathrm{a}}$ & $326^{\mathrm{a}}$ & $547^{\mathrm{b}}$ & $45 \cdot 9$ \\
& $172^{\mathrm{a}}$ & $151^{\mathrm{a}}$ & $118^{\mathrm{b}}$ & 9 \\
\hline
\end{tabular}

a, b, c Within a row, mean values with different superscript letters were significantly different $(P<0.05)$.

* For details of diets and procedures, see pp. 8487.

\section{Statistical analysis}

All values were analysed by means of analysis of variance. A randomized block design was used, in which the animals were the blocks (Cochran \& Cox, 1957). Although the treatments are confounded by time it is assumed that differences are due to the test sugar. The Genstat 5 package (Oxford University Press, 1987) was used to calculate the analysis of variance. The treatment factors were the combination of the type of sugar and the dietary level. Then the treatment means were compared using the least significance differences test. All statements of significance are based on a probability of $P<0-05$.

\section{RESULTS}

The pigs were healthy and consumed their daily feed allowance completely for all experimental treatments.

\section{Expt $A$}

Intake of DM and water, output of digesta, and DM content of digesta measured in cannulated pigs on D-glucose or D-xylose diets are given in Table 3. Since the output of digesta was measured over $12 \mathrm{~h} / \mathrm{d}$, intake of DM and water is also presented over a $12 \mathrm{~h}$ period. There were significant differences in DM intake among the treatments. These differences were caused by the feeding system applied, since this system was coupled with live weight of the pigs. Water intake of pigs fed on the Gluc diet $(200 \mathrm{~g}$ D-glucose $/ \mathrm{kg})$ was significantly lower compared with the LL-Xyl $(100 \mathrm{~g} \mathrm{D-xylose} / \mathrm{kg})$ and HL-Xyl $(200 \mathrm{~g} \mathrm{D}-$ xylose $/ \mathrm{kg}$ ) diets. Pigs fed on the Gluc diet produced on average $255 \mathrm{~g}$ wet digesta $/ 12 \mathrm{~h}$, which value was increased to 326 and $547 \mathrm{~g} / 12 \mathrm{~h}$ when pigs were fed on the LL-Xyl and HL-Xyl diets respectively. The amount of digesta produced in pigs on the HL-Xyl diet was significantly different from that of pigs on the Gluc and LL-Xyl diets. The increase in digesta output in pigs on the LL-Xyl and HL-Xyl diets was associated with a decrease in DM content of the digesta. However, the latter was more pronounced on the HL-Xyl diet than on the LL-Xyl diet.

Apparent digestibility values for DM, OM, GE, N, D-glucose and D-xylose are shown in Table 4. In pigs fed on the Gluc and LL-Xyl diets, similar digestibility coefficients for DM, $\mathrm{OM}, \mathrm{GE}$ and $\mathrm{N}$ were observed. However, in pigs fed on the HL-Xyl diet digestibility of $\mathrm{DM}, \mathrm{OM}, \mathrm{GE}$ and $\mathrm{N}$ decreased significantly. The apparent ileal digestibility of $\mathrm{D}$-glucose and D-xylose was found to be close to $100 \%$.

Digesta $\mathrm{pH}$, VFA concentrations in the digesta, and ileal flow of VFA are given in Table 5. The $\mathrm{pH}$ decreased significantly from 6.5 in digesta of pigs on the Gluc diet to 6.2 and 6.0 
Table 4. Expt $A^{*}$. Apparent ileal digestibility coefficients of dry matter $(D M)$, organic matter $(O M)$, gross energy $(G E)$, nitrogen, $D$-glucose and $D$ - $x y$ lose, measured in cannulated pigs fed on D-glucose and D-xylose $(100(L L-X y l)$ or $200(H L-X y l) \mathrm{g} / \mathrm{kg})$ diets

(Mean values of four pigs per treatment)

\begin{tabular}{lccccc}
\hline \hline Diet $\ldots$ & Gluc & LL-Xyl & HL-Xyl & SEM & df \\
\hline DM & $86 \cdot 2^{\mathrm{a}}$ & $85 \cdot 7^{\mathrm{a}}$ & $81 \cdot 9^{\mathrm{b}}$ & $1 \cdot 00$ & 6 \\
OM & $87 \cdot 6^{\mathrm{a}}$ & $87 \cdot 2^{\mathrm{a}}$ & $84 \cdot 7^{\mathrm{b}}$ & $0 \cdot 71$ & 6 \\
GE & $87 \cdot 6^{\mathrm{a}}$ & $87 \cdot 5^{\mathrm{a}}$ & $84 \cdot 5^{\mathrm{b}}$ & 0.62 & 6 \\
N & $90 \cdot 3^{\mathrm{a}}$ & $89 \cdot 1^{\mathrm{a}}$ & $87 \cdot 2^{\mathrm{b}}$ & 0.47 & 6 \\
D-glucose & $99 \cdot 3$ & - & - & - & - \\
D-xylose & - & $98 \cdot 7^{\mathrm{a}}$ & $98 \cdot 6^{\mathrm{a}}$ & $0 \cdot 23$ & 3 \\
\hline \hline
\end{tabular}

${ }^{a}, \mathrm{~b}$ Within a row, mean values with different superscript letters were significantly different $(P<0 \cdot 05)$.

* For details of diets and procedures, see pp. 84-87.

Table 5. Expt $A^{*}$. Digesta $p H$, concentrations of volatile fatty acids (VFA) in digesta and ileal flow of VFA, measured in cannulated pigs fed on D-glucose and D-xylose (100 (LL-Xyl) or $200(H L-X y l) \mathrm{g} / \mathrm{kg})$ diets

(Mean values of four pigs per treatment)

\begin{tabular}{|c|c|c|c|c|}
\hline Diet... & Gluc & LL-Xyl & HL-Xyl & $\begin{array}{l}\text { SEM } \\
(\mathrm{df} 6)\end{array}$ \\
\hline \multicolumn{5}{|c|}{$\begin{array}{l}\mathrm{pH} \text {, and concentrations of VFA } \\
\text { in digesta }(\mathrm{mg} / 100 \mathrm{~g})\end{array}$} \\
\hline $\mathrm{pH}$ & $6 \cdot 5^{\mathrm{a}}$ & $6 \cdot 2^{\mathrm{b}}$ & $6 \cdot 0^{\mathrm{c}}$ & 0.06 \\
\hline Total VFA & $437^{\mathrm{a}}$ & $644^{\mathrm{ab}}$ & $930^{\mathrm{b}}$ & $86 \cdot 6$ \\
\hline \multicolumn{5}{|l|}{ Individual VFA } \\
\hline Acetic acid & $270^{\mathrm{a}}$ & $478^{\mathrm{ab}}$ & $654^{\mathrm{b}}$ & $61 \cdot 2$ \\
\hline Propionic acid & $77^{\mathrm{a}}$ & $79^{a}$ & $121^{\mathrm{a}}$ & 17.9 \\
\hline Butyric acid & $5 I^{a}$ & $49^{a}$ & $75^{\mathrm{a}}$ & $11 \cdot 4$ \\
\hline Isobutyric acid & $12^{\mathrm{a}}$ & $11^{\mathrm{a}}$ & $22^{b}$ & $2 \cdot 0$ \\
\hline Valeric acid & $13^{\mathrm{a}}$ & $14^{\mathrm{a}}$ & $27^{\mathrm{b}}$ & $2 \cdot 4$ \\
\hline Isovaleric acid & $14^{\mathrm{a}}$ & $13^{\mathrm{a}}$ & $31^{\mathrm{D}}$ & $2 \cdot 8$ \\
\hline \multicolumn{5}{|c|}{ Ileal flow of VFA $(\mathrm{mg} / 12 \mathrm{~h})$} \\
\hline Total VFA & $1106^{\mathrm{a}}$ & $2062^{\mathrm{b}}$ & $4888^{\circ}$ & $123 \cdot 7$ \\
\hline \multicolumn{5}{|l|}{ Individual VFA } \\
\hline Acetic acid & $684^{\mathrm{a}}$ & $1508^{b}$ & $3447^{\circ}$ & $99 \cdot 2$ \\
\hline Propionic acid & $196^{\mathrm{a}}$ & $253^{\mathrm{a}}$ & $630^{\mathrm{b}}$ & $42 \cdot 0$ \\
\hline Butyric acid & $125^{\mathrm{a}}$ & $171^{a}$ & $386^{\mathrm{b}}$ & 37.6 \\
\hline Isobutyric acid & $31^{\mathrm{a}}$ & $34^{\mathrm{a}}$ & $115^{b}$ & 6.4 \\
\hline Valeric acid & $33^{\mathrm{a}}$ & $48^{a}$ & $146^{b}$ & $10 \cdot 3$ \\
\hline Isovaleric acid & $37^{\mathrm{a}}$ & $48^{\mathrm{a}}$ & $164^{\mathrm{b}}$ & $7 \cdot 7$ \\
\hline
\end{tabular}

a. b,c Within a row, mean values with different superscript letters were significantly different $(P<0.05)$.

* For details of diets and procedures, see pp. 84-87.

when they were fed on the LL-Xyl and HL-Xyl diets respectively; the latter two values were also significantly different from each other. The decrease in $\mathrm{pH}$ on the LL-Xyl and HL-Xyl diets concurred with the appearance of greater amounts of VFA in the digesta. The increase in total VFA concentrations in pigs on the LL-Xyl diet was about $50 \%$, but not significant. This was due to the large differences between animals within the treatments. When pigs were fed on the HL-Xyl diet, total VFA concentrations in digesta increased significantly to about $210 \%$ when compared with the Gluc treatment. The increase in total VFA 
concentrations on the HL-Xyl diet was reflected in all individual VFA fractions. In terms of ileal flow of VFA the differences between the treatments are much greater, since pigs on the LL-Xyl and HL-Xyl diets produced greater quantities of digesta than when fed on the Gluc diet.

\section{Expt $B$}

The mean values for DM and water intake, output of fresh faeces, DM content of faeces and output of urine in pigs fed on the Gluc, LL-Xyl and HL-Xyl diets over a $12 \mathrm{~h}$ period, are given in Table 6. There were significant differences in DM intake among the treatment groups. However, as already stated in Expt $A$, these differences were caused by the feeding system applied. Water intake and urine output tended to increase and the DM content of faeces tended to decrease when the pigs were fed on the LL-Xyl diet. When fed on the HL$\mathrm{Xyl}$ diet, water intake as well as output of urine and fresh faeces increased significantly compared with the Gluc and LL-Xyl diets. In addition, the DM content of faeces in pigs fed on the HL-Xyl diet was significantly lower when compared with the Gluc diet.

Apparent faecal digestibility coefficients for DM, OM, GE and N, retention of $N$, and the urinary excretion of glucose, xylose, energy and $\mathrm{N}$ are given in Table 7 . Similar results for apparent faecal digestibility of DM, OM, GE and N were achieved on the Gluc and LLXyl diets. When fed on the HL-Xyl diet, digestibilities of all four substances decreased significantly. $\mathrm{N}$ retention was calculated from the intake of $\mathrm{N}$ and the losses of $\mathrm{N}$ into the faeces and urine. When fed on the HL-Xyl diet, significantly less $\mathrm{N}$ was retained than when feeding the Gluc and LL-Xyl diets. This is due to both a lower $\mathrm{N}$ digestibility and a higher amount of $\mathrm{N}$ excreted in the urine on the HL-Xyl diet. The losses of xylose into the urine were considerable. When pigs were fed on the LL-Xyl diet, $44.5 \%$ of the D-xylose intake was excreted in the urine. This percentage increased significantly to 52.6 when pigs were fed on the HL-Xyl diet. As a result of the xylose losses into the urine, urinary excretion of energy also increased significantly in pigs on the LL-Xyl and HL-Xyl diets.

\section{DISCUSSION}

The choice of the experimental design needs to be considered. Latin squares are often used as an experimental design in balance studies with pigs, especially in trials in which the diets are fed in sequence, the diet sequence being different for each pig (Goedhart, 1990). The advantages of using Latin squares are that variation between animals and those arising from a common time trend between periods can be equilibrated. However, this is only true when there are no carry-over effects. For D-xylose, the results of a previous tentative study showed that carry-over effects of this pentose sugar cannot be excluded. Therefore, for the sake of safety in the present trials each pig was fed on the sugars in the sequence of Dglucose (Gluc), low-level D-xylose (LL-Xyl; $100 \mathrm{~g} / \mathrm{kg}$ ) and high-level D-xylose (HL-Xyl; $200 \mathrm{~g} / \mathrm{kg}$ ). One disadvantage of feeding experimental diets in sequence is that faecal digestibilities may be affected by a time-period $\times$ treatment interaction, because the digestive capacity of the pig large intestine increases with increasing age. Considering the results reported by McConnell et al. (1971, 1972), Hennig et al. (1979) and Goedhart (1990), the changes in faecal DM, OM, GE and N digestibilities in Expt B as affected by age would have been less than $1 \%$. Furthermore, it should be noted that the feeding system applied in our design may have induced changes in intake of water, and output of wet digesta, fresh faeces and urine. However, when corrected for the differences in DM intake among the treatments, it can be calculated that there are still large differences in these characteristics between the D-Gluc and HL-Xyl diets.

The results obtained in the present study indicate that D-xylose was digested almost completely at the terminal ileum; this would suggest an almost complete absorption of this 
Table 6. Expt $B^{*}$. Intake $(\mathrm{g} / 12 \mathrm{~h})$ of dry matter $(D M)$ and water, output $(\mathrm{g} / 12 \mathrm{~h})$ of faeces and urine, and DM content $(\mathrm{g} / \mathrm{kg})$ of faeces, measured in non-cannulated pigs fed on D-glucose and D-xylose $(100(L L-X y l)$ or $200(H L-X y l) \mathrm{g} / \mathrm{kg})$ diets

(Mean values of four pigs per treatment)

\begin{tabular}{lcccc}
\hline \hline Diet... & Gluc & LL-Xyl & HL-Xyl & $\begin{array}{c}\text { SEM } \\
\text { (df 6) }\end{array}$ \\
\hline Intake of DM & $322^{\mathrm{a}}$ & $339^{\mathrm{b}}$ & $355^{\mathrm{c}}$ & $0 \cdot 1$ \\
Intake of water & $655^{\mathrm{a}}$ & $736^{\mathrm{a}}$ & $963^{\mathrm{b}}$ & $36 \cdot 6$ \\
Output of fresh faeces & $35^{\mathrm{a}}$ & $34^{\mathrm{a}}$ & $68^{\mathrm{b}}$ & $3 \cdot 4$ \\
DM content of faeces & $482^{\mathrm{a}}$ & $448^{\mathrm{ab}}$ & $419^{\mathrm{b}}$ & 14 \\
Output of urine & $326^{\mathrm{a}}$ & $407^{\mathrm{a}}$ & $676^{\mathrm{b}}$ & $28 \cdot 8$ \\
\hline
\end{tabular}

a.b,c Within a row, mean values with different superscript letters were significantly different $(P<0 \cdot 05)$.

* For details of diets and procedures, see pp. 84-87.

Table 7. Expt $B^{*}$. Apparent faecal digestibility coefficients of dry matter (DM), organic matter $(O M)$, gross energy $(G E)$ and nitrogen, retention of $N(\%$ of intake), and urinary excretion (\% of intake) of glucose, xylose, energy and $N$, measured in non-cannulated pigs fed on D-glucose and D-xylose $(100(L L-X y l)$ or $200(H L-X y l) \mathrm{g} / \mathrm{kg})$ diets

(Mean values of four pigs per treatment)

\begin{tabular}{lccccc}
\hline Diet ... & Gluc & LL-Xyl & HL-Xyl & SEM & df \\
\hline Digestibilities & & & & & \\
DM & $94 \cdot 9^{\mathrm{a}}$ & $95 \cdot 5^{\mathrm{a}}$ & $92 \cdot 2^{\mathrm{b}}$ & $0 \cdot 37$ & 6 \\
OM & $95 \cdot 8^{\mathrm{a}}$ & $96 \cdot 5^{\mathrm{a}}$ & $93 \cdot 5^{\mathrm{b}}$ & $0 \cdot 31$ & 6 \\
GE & $95 \cdot 2^{\mathrm{a}}$ & $96 \cdot 0^{\mathrm{a}}$ & $92 \cdot 7^{\mathrm{b}}$ & $0 \cdot 34$ & 6 \\
N & $96 \cdot 1^{\mathrm{a}}$ & $96 \cdot 1^{\mathrm{a}}$ & $93 \cdot 5^{\mathrm{b}}$ & $0 \cdot 44$ & 6 \\
Urinary excretion & & & & & \\
Glucose & + & + & + & & \\
Xylose & - & $44 \cdot 5^{\mathrm{a}}$ & $52 \cdot 6^{\mathrm{b}}$ & $1 \cdot 44$ & 3 \\
Energy & $2 \cdot 2^{\mathrm{a}}$ & $6 \cdot 1^{\mathrm{b}}$ & $9 \cdot 9^{\mathrm{c}}$ & $0 \cdot 83$ & 6 \\
N & $34 \cdot 9^{\mathrm{a}}$ & $35 \cdot 1^{\mathrm{a}}$ & $38 \cdot 7^{\mathrm{b}}$ & $0 \cdot 71$ & 6 \\
Retention of N & $61 \cdot 2^{\mathrm{a}}$ & $60 \cdot 9^{\mathrm{a}}$ & $54 \cdot 8^{\mathrm{b}}$ & $1 \cdot 00$ & 6 \\
\hline
\end{tabular}

a,b,c Within a row, mean values with different superscript letters were significantly different $(P<0 \cdot 05)$.

* For details of diets and procedures, see pp. 84-87.

+ Small traces $(0 \cdot 2-1 \cdot 2 \mathrm{~g} / \mathrm{l})$ of glucose were found in the urine of all experimental treatments.

pentose sugar per se. On the other hand, administration of D-xylose to pigs was associated with an increase in ileal flow of VFA and a decrease in $\mathrm{pH}$. Both symptoms point to a more extensive microbial activity in the small intestine of pigs on the D-xylose diets. This may have resulted from the differences in rates of absorption from the small intestine between D-glucose and D-xylose as reported by Miller \& Lewis (1932) in rats, and Bogner (1961) and Wagh \& Waibel (1967a) in chicks. These authors showed that absorption velocity of Dxylose was lower than that of D-glucose. The presence of unabsorbed xylose in the small intestine may stimulate microbial activity. Thus, the observed high ileal digestibility of Dxylose in the present study could partly be due to a microbial degradation of this sugar. The extent of microbial degradation of D-xylose in the pig small intestine cannot be derived simply from the differences in ileal flow of VFA between the D-glucose and D-xylose treatments, because some of the VFA will be absorbed already in the small intestine. In addition to D-xylose, other readily fermentable components in the diet may also be attacked 
by an increased intestinal bacterial activity. It is likely that the depression in apparent ileal digestibility of $\mathrm{N}$ in pigs on the $200 \mathrm{~g}$ D-xylose $/ \mathrm{kg}$ diet is, at least partly, a result of the increased microbial activity with this diet. As protein is part of DM, OM and GE, this will also affect the digestibility of these substances. However, the reduction in ileal digestibility of DM, OM and GE on the HL-Xyl (200 g D-xylose/kg) diet can only partly be explained by the depression in $\mathrm{N}$ digestibility. Additionally, the increase in ileal digesta flow may also be responsible for the depression in digestibility of DM, OM and GE on the HL-Xyl diet. This higher ileal digesta flow can be explained by the presence of unabsorbed xylose in the small intestine which will lead to an inflow of water into the intestinal lumen in order to keep osmolality constant (van Weerden, 1959; Hof, 1980).

The magnitude of the difference in ileal DM, OM, GE and $\mathrm{N}$ digestibility between the treatments was maintained at a similar level in the faecal digestibility values (Table $4 v$. Table 7). These results may suggest that microbial activity in the pig large intestine was not markedly changed when the $\mathrm{D}$-xylose diets were fed. The observed depressed $\mathrm{N}$ retention on the HL-Xyl diet is a result of the depressed $\mathrm{N}$ digestibility on the one hand and of a higher urinary excretion on the other. Since the experimental diets were fed in sequence, the higher urinary excretion of $\mathrm{N}$ on the HL-Xyl diet could be partly due to an age effect (Carr et al. 1977).

It is well recognized that a portion of the ingested D-xylose appears in the urine of man (Loos, 1954; Fowler \& Cooke, 1960), rats (Arnal-Peyrot \& Adrian, 1974) and pigs (Wise et al. 1954). This observation is confirmed in the present work. However, there is a scarcity of information about the relationship between the dietary inclusion level of D-xylose and the urinary excretion of this sugar. Wagh \& Waibel (1966) reported, that in chicks the ME value of $\mathrm{D}$-xylose was decreased when the dietary level of this sugar was increased. Their finding may provide some evidence of an increased urinary excretion of D-xylose in percentage of intake when the dietary level of this sugar is increased, since Longstaff et al. (1988) reported that apparent digestibility of D-xylose in chicks was nearly $100 \%$. In the present study, urinary excretion of xylose as a percentage of intake increased when the dietary level of D-xylose was increased from 100 to $200 \mathrm{~g} / \mathrm{kg}$. When fed on the $100 \mathrm{~g} \mathrm{D}$ xylose $/ \mathrm{kg}$ diet, $44.5 \%$ of the D-xylose intake was excreted via the urine pathway. This percentage increased to 52.6 when fed on the $200 \mathrm{~g} \mathrm{D}$-xylose $/ \mathrm{kg}$ diet. This dosagedependent urinary excretion of $\mathrm{D}$-xylose in percentage of intake may be connected with the low renal threshold for this sugar as suggested by Loos (1954). The differences in urinary excretion of xylose between the two D-xylose treatments are not reflected in the urinary excretion of energy. Calculations have indicated that when the increases in urinary excretion of energy over the D-glucose treatment were contributed to D-xylose, this would represent about $45 \%$ of the D-xylose intake at both dietary levels.

In conclusion, it can be stated that utilization of D-xylose in pigs at dietary inclusion levels of $100 \mathrm{~g}$ and $200 \mathrm{~g} / \mathrm{kg}$ is low. Apart from the great losses of $\mathrm{D}$-xylose into the urine, at least part of this pentose sugar is fermented in the intestinal tract of pigs, which process is coupled with considerable losses in energy. In addition, at high dietary levels this pentose sugar may induce unwanted nutritive problems together with a higher excretion of urine and faeces. Considering these aspects, the benefits of a hydrolysis of the hemicellulose fraction in pig diets seem to be doubtful as compared with a fermentation of this fraction in the hind-gut of pigs. There are no findings available on the extent of release of D-xylose in the gastrointestinal tract of pigs as a result of enzyme inclusion in pig diets. Carré \& Brillouet (1986) determined the content and composition of various feedstuffs used by single-stomach farm animals. From their findings it can be calculated that by a complete hydrolysis of non-starch polysaccharides in pig diets based on cereals, soya-bean-oil meal and cereal byproducts, about $4 \%$ D-xylose will be released. Considering the results of Wagh 
\& Waibel (1966) with chicks, it might be expected that in pigs utilization of D-xylose will also be much better at low than at high dietary levels. This was confirmed in a recently performed study (J. B. Schutte, G. M. Beelen, G. B. Derksen \& J. Wiebenga; unpublished results) with pigs, in which D-xylose was tested at graded dietary levels of $25-100 \mathrm{~g} / \mathrm{kg}$. The results of that study showed that ME content of $\mathrm{D}$-xylose was significantly decreased when the dietary level of this pentose sugar was increased. Further studies will be required to clarify the utilization and metabolism of D-xylose in pigs in relation to the dietary inclusion level.

The authors would like to thank Mr P. van Leeuwen for surgical assistance, Messrs G. B. Derksen and J. Wiebenga for statistical analysis of the data, and Dr E. J. van Weerden and Professor S. Tamminga for valuable discussions.

\section{REFERENCES}

Agricultural Research Council (1981). The Nutrient Requirements of Pigs. Slough: Commonwealth Agricultural Bureaux.

Arnal-Peyrot, F. \& Adrian, J. (1974). Métabolisme des pentosanes de céréale chez le rat. (Metabolism of cereal pentosans in rat.) International Journal for Vitamin and Nutrition Research 44, 543-552.

Association of Official Analytical Chemists (1975). Official Methods of Analysis, 12th ed. Washington, DC: Association of Official Analytical Chemists.

Bogner, P. H. (1961). Alimentary absorption of reducing sugars by embryos and young chicks. Proceedings of the Society of Experimental Biology and Medicine 107, 263-267.

Carr, J. R., Boorman, K. N. \& Cole, D. J. A. (1977). Nitrogen retention in the pig. British Journal of Nutrition 37, 143-155.

Carré, B. \& Brillouet, J. M. (1986). Yield and composition of cell wall residues isolated from various feedstuffs used for non-ruminant farm animals. Journal of the Science of Food and Agriculture 37, 341-351.

Cochran, W. G. \& Cox, G. M. (1957). Experimental Designs, 2nd ed. New York: Wiley and Sons.

Cori, F. (1925). The fate of sugar in the animal body. 1. The rate of absorption of hexoses and pentoses from the intestinal tract. Journal of Biological Chemistry 66, 691-715.

Fowler, D. \& Cooke, W. T (1960). Diagnostic significance of D-xylose excretion test. Gut 1, 67-70.

Goedhart, P. W. (1990). Experimental design for comparative digestibility trials with pigs: limitations of Latin squares. Anima! Production 50, 373-378.

Hennig, U., Bock, H. D., Wünsche, J. \& Kreienbring, F. (1979) Einfluss des Geschlechtes und der Lebendmasse auf die wahre Verdaulichkeit des Proteins und der Aminosäuren verschiedener Futtermittel bei Schweinen. (The infiuence of the sex and live mass of pigs on the actual digestibility of protein and amino acids of various feeds.) Archiv für Tierernährung 29, 1-8.

Hof, G. (1980). An investigation into the extent to which various dietary components, particularly lactose, are related to the incidence of diarrhoea in milk-fed calves. PhD Thesis, Agricultural University of Wageningen, The Netherlands.

Imoto, S. \& Namioka, S. (1978). VFA production in the pig large intestine. Journal of Animal Science 47, 467-487.

Just, A., Fernández, J. A. \& Jørgensen, H. (1983). The net energy value of diets for growth in pigs in relation to the fermentative processes in the digestive tract and the site of absorption of the nutrients. Livestock Production Science 10, 171-186.

Longstaff, M. A., Knox, A. \& McNab, J. M. (1988). Digestibility of pentose sugars and uronic acids and their effect on chick weight gain and caecal size. British Poultry Science 29, 379-393.

Loos, M. (1954). Studies in the utilization of pentoses in diabetes. Acta Medica Scandinavica 148, 425-431.

McConnell, J. C., Barth, K. M. \& Griffin, S. A. (1971). Nutrient digestibility and nitrogen metabolism studies at different stages of growth with fat and lean type swine fed two levels of protein. Journal of Animal Science 32, 654-657.

McConnell, J. C., Barth, K. M. \& Griffin, S. A. (1972). Nitrogen metabolism at three stages of development and its relationship to measurements of carcass composition in fat and lean type swine. Journal of Animal Science 35, 556-560.

Miller, M. M. \& Lewis, H. B. (1932). Pentose metabolism. 1. The rate of absorption of D-xylose and the formation of glucogen in the organism of the white rat after oral administration of D-xylose. Journal of Biological Chemistry 98, 133-140.

Oxford University Press (1987). Genstat 5 Reference Manual. New York: Oxford University Press.

Sweeley, C. C., Bentley, R., Makita, M. \& Wells, W. W. (1963). Gas liquid chromatography of trimethylsilyl derivatives of sugars and related substances. Journal of the American Chemical Society 85, 2497-2507.

Van Es, A. J. H. (1987). Energy utilization of low digestibility carbohydrates. In Low Digestibility Carbohydrates, pp. 121-127 [D. C. Leegwater, V. J. Feron and R. J. J. Hermus, editors]. Wageningen: Pudoc. 
van Leeuwen, P., Huisman, J., Verstegen, M. W. A., van Baak, M. J., van Kleef, D. J., van Weerden, E. J. \& den Hartog, L. A. (1988). A new technique for collection of ileal chyme in pigs. In Proceedings of the Vith International Symposium on Digestive Physiology in the Pig, pp. 289-296. [L. Buraczewska, S. Buraczewski, B. Pastuszewska and T. Zebrowska, editors]. Jablonna Poland: Polish Academy of Sciences.

van Weerden, E. J. (1959). The osmotic pressure and the concentration of some soluble components of the intestinal contents and the faeces of the cow, in relation to the absorption of minerals. PhD Thesis, Agricultural University of Wageningen, The Netherlands.

Wagh, P. V. \& Waibel, P. E. (1966). Metabolizability and nutritional implications of L-arabinose and D-xylose for chicks. Journal of Nutrition $90,207-211$.

Wagh, P. V. \& Waibel, P. E. (1967a). Alimentary absorption of L-arabinose and D-xylose in chicks. Proceedings of the Society of Experimental Biology and Medicine 124, 421-424.

Wagh, P. V. \& Waibel, P. E. (1967 b). Metabolism of L-arabinose and D-xylose by chicks. Journal of Nutrition 92, $491-496$.

Wise, M. B., Barrick, E. R., Wise, G. H. \& Osborne, J. C. (1954). Effects of substituting xylose for glucose in a purified diet for pigs. Journal of Animal Science 13, 365-374. 